\title{
Comparative in vitro Antidiabetic and Antioxidant Activity of Various Extracts of Ficus Species
}

\author{
Shaikh Abusufyan ${ }^{1,2^{*}}$, Mohammed Ibrahim³ ${ }^{3}$, Khan Mohib ${ }^{4}$
}

\section{Shaikh Abusufyan ${ }^{1,2^{*}}$, Mohammed Ibrahim ${ }^{3}$, Khan Mohib ${ }^{4}$}

\section{'Department of Pharmacology, School of Pharmacy, AIKTC, New Panvel, Maharashtra, affiliated to Mumbai University, INDIA. \\ ${ }^{2}$ Research Scholar, Department of Phar- maceutical Sciences, JNTUH, Kukatpally, Telangana, INDIA. \\ ${ }^{3}$ Department of Pharmacy, PNR College Pharmacy, Telangana, INDIA. \\ ${ }^{4}$ Department of Pharmacognosy, Oriental Col- lege of Pharmacy, Navi Mumbai, INDIA. \\ Correspondence \\ Shaikh Abusufyan \\ School of Pharmacy, AIKTC, New Panvel, Maharashtra 410206, INDIA. \\ Phone No: +91-8286022587 \\ E mail Id: abushaikh07@yahoo.com \\ History \\ - Submission Date: 23-11-2017; \\ - Review completed: 19-12-2017; \\ - Accepted Date: 31-12-2017}

DOI : 10.5530/pj.2018.2.59

Article Available online

http://www.phcogj.com/v10/i2

\section{Copyright}

(C) 2018 Phcog.Net. This is an openaccess article distributed under the terms of the Creative Commons Attribution 4.0 International license.

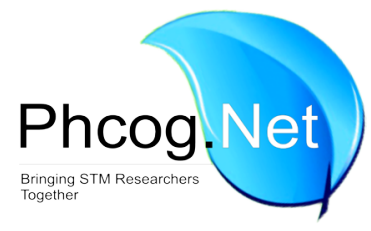

\begin{abstract}
Introduction: Ficus religiosa, Ficus benghalensis and Ficus glomerata are plants from Ficus species used traditionally for the treatment of various ailments. This study aimed to investigate in vitro antidiabetic and antioxidant activity of three plants from Ficus species and effect of extracting solvents, total flavonoids and phenolics content on its in vitro activity. Methods: Dried leaf powder was extracted successively by using solvents with increasing order of polarity index (PI). In vitro antioxidant (RP: reducing power assay, DPPH: 2,2-diphenyl-1-picrylhydrazyl assay and HP: Hydrogen peroxide assay) and antidiabetic ( $\alpha A$ : $\alpha$-amylase assay and $\alpha \mathrm{G}$ : $\alpha$-glucosidase assay) activities as well as total flavonoid (TF) and total phenolic (TP) contents of extracts were evaluated. The correlation between in vitro activities and solvent polarity index, total flavonoid and phenolic content were established by using pearson's correlation coefficient (R). Results: Strong positive correlation was observed with $\mathrm{PI}$ of extracting solvents and TP content of Ficus religiosa (PI/TP, $\mathrm{R}=0.8159)$ and Ficus glomerata $(\mathrm{PI} / \mathrm{TP}, \mathrm{R}=0.9172)$. Comparatively benzene and water extracts of Ficus glomerata were found to have significantly $(P<0.05)$ highest in vitro antidiabetic and antioxidant activity respectively. Strong positive correlation was observed between TF and $\alpha \mathrm{G}$ inhibitory (TF/ $\alpha \mathrm{G}, \mathrm{R}=0.793$ ) effects of Ficus benghalensis. In addition, strong positive correlation observed between TP and antioxidant activity (TP/DPPH, $R=0.9744$; TP/RP, $R=0.9514$ and TP/HP, $R=0.8108$ ) of Ficus glomerata. Conclusions: Finding of our research will help in selection of solvents for extracting antidiabetic and antioxidant rich phytoconstituents from Ficus species.

Key words: Antidiabetic, Antioxidant, Ficus benghalensis, Ficus glomerata, Ficus religiosa.
\end{abstract}

\section{INTRODUCTION}

Plants are source of abundant natural bioactive phytochemicals with health-promoting activities like antidiabetic, antioxidant, anti-inflammatory, antibacterial, antihypertensive, analgesic etc. Flavonoids and phenolics compounds are most widely occurring groups of phytochemicals present in plants. There were several studies that reports biological activity of these group of phytochemicals. In addition, extensive research is being conducted to investigate new plant related drugs and to identify appropriate extracting solvent for extraction of phytoconstituent with desired pharmacological action. Diabetes is a serious metabolic disorder affecting millions of life. ${ }^{1,2} \mathrm{~A}$ number of studies showed that the diabetes mellitus associated oxidative stress lead to various macro and microvascular diabetic complications. ${ }^{3,4}$ Plants belong to the Ficus species are well known in traditional system of medicine. Few of such plants are Ficus religiosa, Ficus benghalensis and Ficus glomerata. Extract of these plants from different extracting solvents were reported for treatment of diabetes, stomach ache, piles, skin diseases, ulcer, dysentry, inflammation, oxidative stress and cancer. ${ }^{5}$ One of the reasons for activities of these plants extracts might be due to presence of varying proportion of different phytoconstituents that depends on the selection of appropriate extracting solvents.

The present research work is undertaken to study comparative in vitro antidiabetic and antioxidant activities in the petroleum ether, benzene, chloroform, ethanol and water extracts of leaf of Ficus religiosa, Ficus benghalensis and Ficus glomerata. In addition, this study includes comparative quantitative estimation of total flavonoids and phenolics content in the extracts.

\section{MATERIAL AND METHODS}

\section{Chemicals and reagents}

a-glucosidase, $\alpha$-amylase enzymes, p-nitropheynyla-glucopyranoside and DPPH were purchased from Sisco Research Laboratories Pvt. Ltd. Whereas all other chemicals were purchased from SD Fine Chemicals, Mumbai, and were of AR grade.

\section{Plant Material}

The leaves of Ficus religiosa, Ficus benghalensis and Ficus glomerata were collected from Sindhudurg district of Maharashtra, India. The specimens were 
authenticated by Dr. A. S. Upadhye of Agharkar Research Institute, Pune, India.

\section{Preparation of Extracts}

The leaves were dried in shade and powdered using mixture grinder. The powder leaf material was successively extracted with the solvents of increasing order polarity such as petroleum ether, benzene, chloroform, ethanol and distilled water. All the extracts obtained are preserved in desiccators for future use.

\section{Determination of total flavonoids content}

Total flavonoids content was determined using the method of Ordon et al. ${ }^{6} \mathrm{~A}$ volume of $0.5 \mathrm{ml}$ of $2 \% \mathrm{AlCl}_{3}$ ethanol solution was added to 0.5 $\mathrm{ml}$ of sample solution. After one $\mathrm{h}$ at room temperature, the absorbance was measured at $420 \mathrm{~nm}$ using Jasco UV-VIS spectrophotometer. Total flavonoids content was calculated as $\mathrm{mg} / \mathrm{g}$ QE.

\section{Determination of total phenolics content}

Total phenolics content in the extracts were determined by the modified Folin-Ciocalteu method as described by Wolfe et al. ${ }^{7}$ Extracts $(100 \mu \mathrm{l})$ was mixed with $5 \mathrm{ml}$ Folin-Ciocalteu reagent and $4 \mathrm{ml}$ (75 g/l) of sodium carbonate. The tubes were vortexed for $15 \mathrm{sec}$ and allowed to stand for $30 \mathrm{~min}$ at $40^{\circ} \mathrm{C}$ for colour development. Absorbance was recorded against reagent blank at $765 \mathrm{~nm}$ using Jasco UV-VIS spectrophotometer. Total phenolics content were expressed as $\mathrm{mg} / \mathrm{g}$ GAE.

\section{DPPH Free radical scavenging assay}

The capability of the extracts to scavenge DPPH free radical was evaluated according to the method of Arabshahi and Urooj. ${ }^{8} 1 \mathrm{ml}$ of sample $(0.1 \mathrm{mg} / \mathrm{ml})$ dissolved in methanol was added to $1 \mathrm{ml}$ of a $1 \mathrm{mM}$ methanolic solution of DPPH. Samples were vortex shaken and left in dark for $30 \mathrm{~min}$. The absorbance of the samples was recorded at $517 \mathrm{~nm}$ and percentage scavenging activities of extracts were calculated by using following equation:

$$
\mathrm{I} \%=\frac{\text { A control }- \text { A sample }}{\text { A control }} \times 100
$$

\section{Reducing power assay}

The reducing power was determined according to the method of Oyaizu. ${ }^{9}$ $2.5 \mathrm{ml}$ of extracts $(0.1 \mathrm{mg} / \mathrm{ml})$ dissolved in methanol were mixed with 2.5 $\mathrm{ml}$ of $200 \mathrm{mmol} / \mathrm{l}$ sodium phosphate buffer ( $\mathrm{pH}$ 6.6) and $2.5 \mathrm{ml}$ of $1 \%$ potassium ferricyanide. The mixture was incubated at $50^{\circ} \mathrm{C}$ for $20 \mathrm{~min}$. After $2.5 \mathrm{ml}$ of $10 \%$ trichloroacetic acid (w/v) were added, the mixture was centrifuged at $650 \mathrm{rpm}$ for $10 \mathrm{~min} .5 \mathrm{ml}$ of upper layer was mixed with $5 \mathrm{ml}$ of water (deionised) and $1 \mathrm{ml}(0.1 \%)$ ferric chloride, and the absorbance was measured at $700 \mathrm{~nm}$. The higher absorbance indicates higher reducing power.

\section{Hydrogen peroxide radical scavenging assay}

Hydrogen peroxide radical scavenging activity of extract was determined according to the method of Jayaprakasha et al ${ }^{10}$ with slight modification. $1 \mathrm{ml}$ of each extract solution $(0.01 \mathrm{mg} / \mathrm{ml})$ prepared in methanol was incubated with $1.5 \mathrm{ml}$ of $20 \mathrm{mM} \mathrm{H}_{2} \mathrm{O}_{2}$ solution prepared in $\mathrm{PBS} \mathrm{pH} 7.4$ for $10 \mathrm{~min}$. The absorbance of the solution was measured at $230 \mathrm{~nm}$. For each extract separate blank was prepared and their absorbance is subtracted from the absorbance of sample. Percentage hydrogen peroxide radical scavenging activity of extracts was calculated by using following equation:

$$
\mathrm{I} \%=\frac{\text { A control }- \text { A sample }}{\text { A control }} \times 100
$$

\section{a-amylase inhibitory assay}

The $a$-amylase inhibitory assay was conducted according to the method described by Okutan et al. ${ }^{11}$ In brief, $500 \mu \mathrm{l}$ of $0.02 \mathrm{mM}$ phosphate buffer $(\mathrm{pH} 6.9,0.06 \mathrm{Mm} \mathrm{Nacl})$ containing $\alpha$-amylase enzyme $(0.05 \mathrm{U} / \mathrm{ml})$ and $500 \mu \mathrm{l}$ extract dissolved in DMSO were incubated at $37^{\circ} \mathrm{C}$ for $5 \mathrm{~min}$. Add $500 \mu \mathrm{l}$ of starch and incubate for exactly $3 \mathrm{~min}$. The reaction was stopped by adding $500 \mu \mathrm{l}$ of DNS reagent and keep it for heating in water bath maintain at $100^{\circ} \mathrm{C}$ for $5 \mathrm{~min}$, removed the test tube from water bath, cooled and add $5 \mathrm{ml}$ of distilled water and measure the absorbance at 540 $\mathrm{nm}$. Percentage $\alpha$-amylase inhibitory activity of extracts was calculated by using following equation:

$$
1 \%=\frac{\text { A control }- \text { A sample }}{\text { A control }} \times 100
$$

\section{a-glucosidase inhibitory assay}

The effect of the plant extracts on $\alpha$-glucosidase activity was determined according to the method described by Kim et al. ${ }^{12}$ The substrate solution of p-nitropheynyl- $\alpha$ - glucopyranoside (pNPG) $(3.0 \mathrm{mM})$ was prepared in phosphate buffer $(20 \mathrm{mM}), \mathrm{pH}$ 6.9. $100 \mu \mathrm{L}$ of $\alpha$-glucosidase $(1.0 \mathrm{U} / \mathrm{ml})$ was pre-incubated with $50 \mu \mathrm{L}$ of the extracts for $10 \mathrm{~min}$. Then $50 \mu \mathrm{L}$ of $3.0 \mathrm{mM}$ (pNPG) as a substrate dissolved in $20 \mathrm{mM}$ phosphate buffer ( $\mathrm{pH}$ 6.9) was added to start the reaction. The reaction mixture was incubated at $37^{\circ} \mathrm{C}$ for $20 \mathrm{~min}$ and stopped by adding $2 \mathrm{ml}$ of $0.1 \mathrm{M} \mathrm{Na}_{2} \mathrm{CO}_{3}$. The $\alpha$-glucosidase activity was determined by measuring the yellow colored para-nitrophenol released from pNPG at $405 \mathrm{~nm}$ and percentage a-glucosidase inhibitory activity of extracts were calculated by using following equation:

$$
\mathrm{I} \%=\frac{\text { A control }- \text { A sample }}{\text { A control }} \times 100
$$

\section{Statistical analysis}

All the determinations were performed in triplicate. Statistical analysis was performed using one way ANOVA followed by post-hoc Tukey's HSD Test at the significance level $\mathrm{P}<0.05$ and $\mathrm{P}<0.01$. Data were also evaluated using Pearson's correlation coefficients to identify relationships between total flavonoids, total phenolics contents and in vitro antioxidant and antidiabetic activities of leaves of Ficus species.

\section{RESULTS AND DISCUSSION}

Phytochemicals such as phenolics and flavonoidal compounds present in the various herbs are well known for its antioxidant and antidiabetic activity. ${ }^{9}$ For this reason there are interests in using phenolics and flavonoids rich extracts in the treatment of diabetes and its complications. In present study five different solvents including petroleum ether, benzene, chloroform, ethanol, water with increase in order of their polarity index were used.

Polarity of extracting solvents have significantly $(\mathrm{P}<0.05)$ affected both measured total flavonoids and phenolics content. Total flavonoids content is varied from 361.45 to $93.96 \mathrm{mg} Q \mathrm{QE} / \mathrm{g}$, whereas total phenolics content is varied from 144.04 to $4.50 \mathrm{mg}$ GAE/g of extract. When total flavonoid content of each extract was compared, chloroform extract of Ficus religiosa and Ficus glomerata extracts were found to have significantly $(\mathrm{p}<0.05)$ higher content of total flavonoids (Figure 1A). However, when 


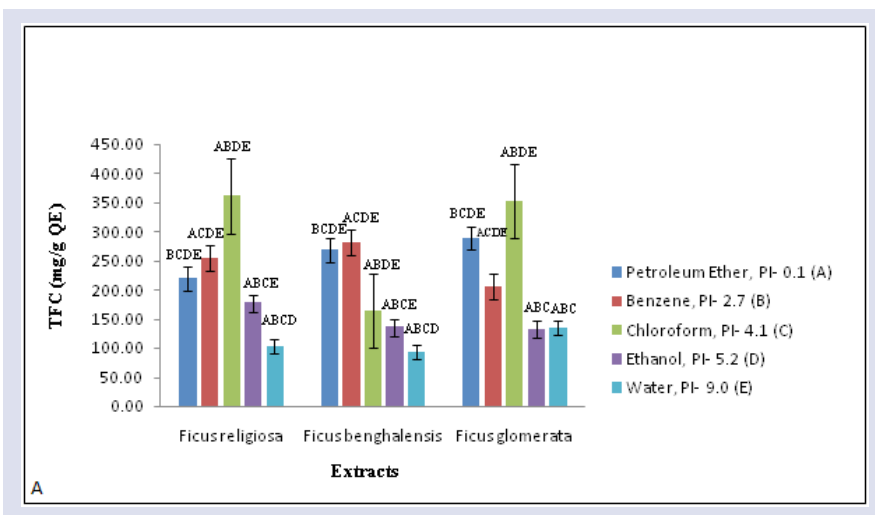

Figure 1 (A): Total flavonoids content of leaves of Ficus species.

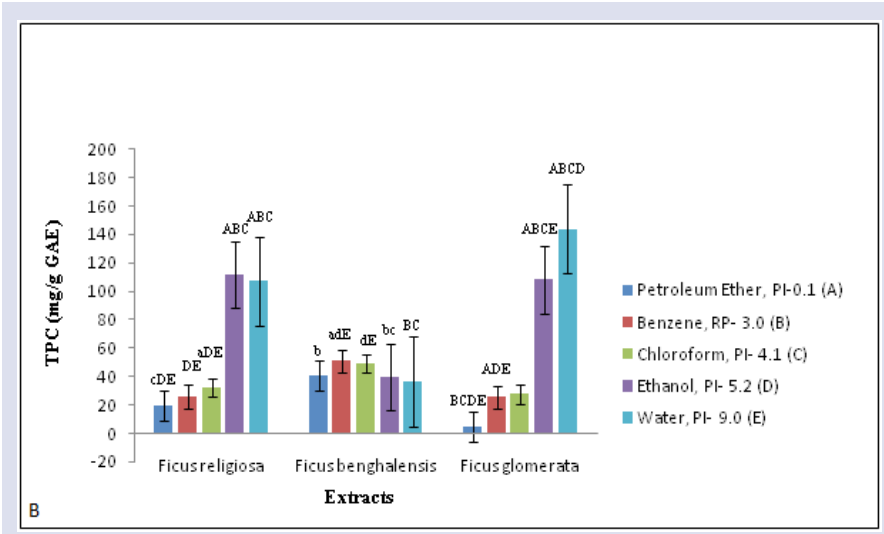

Figure 1 (b): Total phenolics content of leaves of Ficus species. Figure 1: Total flavonoids content (A) and total phenolics content (B) of leaves of Ficus species. Data expresses as mean \pm SEM $(n=3)$. Lower case letters indicate significant differences of $P<0.05$ and capital letters indicate significant difference of $\mathrm{P}<0.01$ as compared to different solvent extracts. PI: Polarity index, TFC: Total flavonoids content, TPC: Total phenolics content, QE: Quercetin equivalent, GAE: Gallic acid equivalent.

the phenolics content of each extract was compared with the others, water extract of Ficus glomerata and ethanol extract of Ficus religiosa were found to have significantly $(\mathrm{p}<0.05)$ higher phenolics content (Figure 1B). Strong positive correlation was found between polarity index of extracting solvents and phenolics content of Ficus religiosa and Ficus glomerata (Table 1) which indicate the role of more polar solvent in extraction of phenolics compound. However, weak negative correlation was found between polarity index of extracting solvents and phenolics content of Ficus benghalensis. This different trend indicates that the phenolics content may change from species to species. Moderate to strong negative correlation was found between polarity index of extracting solvents and flavonoids content in all three Ficus species which indicate the ability of less to moderate polar solvents in extracting flavonoidal compounds (Table 1).

In vitro antidiabetic activity of each extract was estimated by $a$-amylase and $\alpha$-glucosidase inhibitory assay. The $\alpha$-amylase and $\alpha$-glucosidase inhibitory activities of extracts were found to be significantly $(\mathrm{P}<0.05)$ differ among the tested plants. Significantly high $\alpha$-amylase inhibitory and a-glucosidase inhibitory activity was found with benzene and chloroform extract of Ficus gloemrata (Figure 2A and 2B). Three negative values of $\alpha$-amylase inhibition were observed with benzene and chloroform extracts of Ficus religiosa and ethanol extract of Ficus benghalensis (Figure 2A). Also there is one negative value of $\alpha$-glucosidase inhibition was observed for ethanol extract of Ficus benghalensis (Figure 2A). This indicates activation of these enzymes by the respective extracts rather being inhibited. This type of negative value of enzyme inhibitions was also reported by Bahman $\mathrm{N}$ et al. ${ }^{13}$ Overall in both the assay benzene extract of Ficus glomerata showed highest inhibition of both the enzymes. Moderate to strong positive correlations were found between total flavonoids content and $\alpha$-amylase and $\alpha$-glucosidase inhibitory activities of Ficus benghalensis and Ficus glomerata (Table 2) which indicate that the presence of flavonoids in the extract might be responsible for their activity. $\alpha$-amylase and $\alpha$-glucosidase are the main enzymes responsible for the conversion of starch to more simple sugars. Thus, the inhibitors of these enzymes delay carbohydrate digestion and reduce the rate of absorption of glucose. As a result, this type of drugs can control postprandial rise in blood glucose level.

The antioxidant activity of each extract was monitored by using the $\mathrm{DPPH}$ radical scavenging assay, reducing powers assay and hydrogen peroxide radical scavenging assay. All the tested plant extracts of Ficus species exhibited significantly different $(\mathrm{P}<0.05)$ antioxidant activities (Figure $3 \mathrm{~A}, 3 \mathrm{~B}$ and $3 \mathrm{C}$ ). Percentage $\mathrm{DPPH}$ and hydrogen peroxide radical scavenging activity of extracts were found to be in the range from 99.02 to 47.51 and 49.43 to 38.98 respectively. Whereas reducing power of extracts expressed as absorbance at $700 \mathrm{~nm}$ were found to be

Table 1: Pearson's correlations coefficient among polarity index of extracting solvents and total flavonoids and total phenolics content of leaves of Ficus species. Data expressed as Pearson's correlations coefficient $(R)$ between PI of solvents selected for extraction and TF and TP content, mean $(n=3)$ of respective plants calculated by using Pearson's correlation coefficient calculator. PI: Polarity index TF: Total flavonoids, TP: Total phenolics.

\begin{tabular}{ccc}
\hline Name of Plant & PI /TF & PI /TP \\
\hline Ficus religiosa & -0.5305 & 0.8159 \\
Ficus benghalensis & -0.878 & (Strong Positive) \\
& (Strong Negative) & -0.422 \\
Ficus glomerata & -0.6186 & 0.9172 \\
& (Moderate Negative) & (Strong Positive) \\
\hline
\end{tabular}

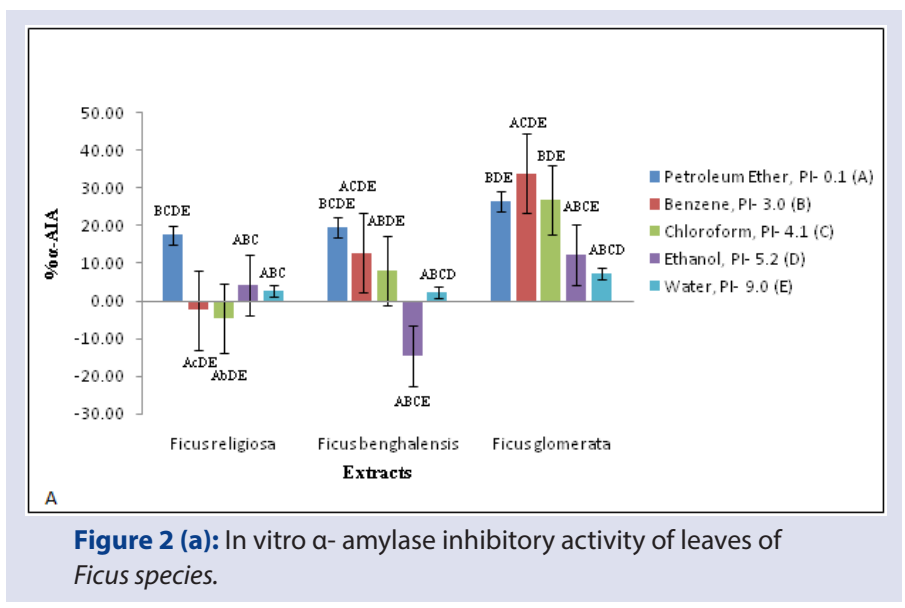




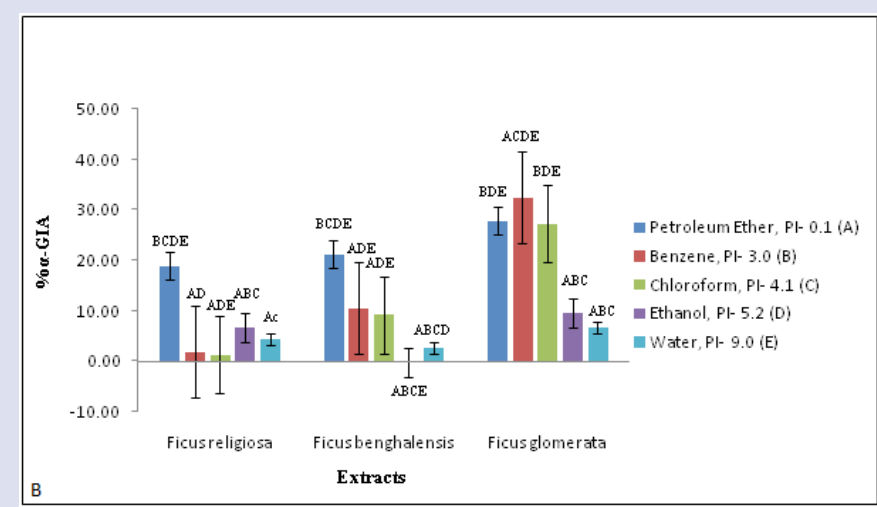

Figure $\mathbf{2}$ (b): a- glucosidase inhibitory activity of leaves of Ficus species.

Figure 2: In vitro a- amylase inhibitory activity (A) and a- glucosidase inhibitory activity (B) of leaves of Ficus species. Data expresses as mean \pm SEM $(n=3)$. Lower case letters indicate significant differences of $\mathrm{P}<0.05$ and capital letters indicate significant difference of $\mathrm{P}<0.01$ as compared to different solvent extracts. Pl: Polarity index, a-AIA: a- amylase inhibitory activity, a-GIA: a- glucosidase inhibitory activity.

in the range from 0.4294 to 0.1422 . When DPPH and hydrogen peroxide radical scavenging activity of extracts was compared, water, ethanol extract of Ficus glomerata and water extract of Ficus religiosa respectively showed significantly $(\mathrm{p}<0.05)$ high antioxidant activity (Figure $3 \mathrm{~A}$ and $3 \mathrm{C})$. When reducing power of extracts were compared, water extract of Ficus glomerata and ethanol extract of Ficus bengalesnsis showed significantly $(\mathrm{p}<0.05)$ high reducing power (Figure $3 \mathrm{~B})$. Overall in all antioxidant activity assays water extracts of Ficus glomerata showed highest anti-

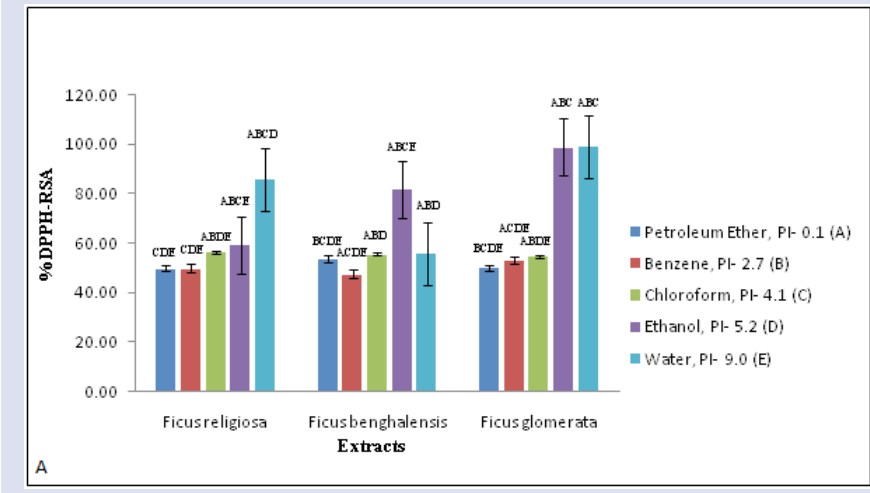

Figure 3 (A): In vitro DPPH radical scavenging activity leaves of Ficus species.

oxidant activity. Moderate to weak correlations were observed between phenolics content and antioxidant activity of Ficus religiosa whereas strong positive correlation was found between phenolics content and antioxidant activity of Ficus glomerata (Table 3) which indicate that the presence of phenolics content in the extract might be responsible for its antioxidant activity.

Other researchers have also reported such type of favourable positive correlation between antioxidant activity and phenolics content. ${ }^{14,15,16}$ It was also found that most polar extracting solvents showed more antioxidant activity and total phenolic content as compared to less polar solvents. It indicate that the polar solvents are important in extracting phytoconstituents with more antioxidant activity and phenolics content which is in agreement with earlier study. ${ }^{17}$

\begin{tabular}{|c|c|c|c|c|c|}
\hline Plant & $\mathrm{TF} /$ & $\mathrm{TF} /$ & $\mathrm{TF} /$ & $\mathrm{TF} /$ & $\mathrm{TF} /$ \\
\hline Name & $a A$ & $\mathrm{aG}$ & DPPH & $\mathrm{RP}$ & $\mathrm{HP}$ \\
\hline Ficus religiosa & $\begin{array}{c}-0.3972 \text { (Weak } \\
\text { Negative) }\end{array}$ & $\begin{array}{c}-0.3143 \text { (Weak } \\
\text { Negative) }\end{array}$ & $\begin{array}{c}-0.6773 \text { (Moderate } \\
\text { Negative) }\end{array}$ & $\begin{array}{c}0.1746 \\
\text { (Weak Positive) }\end{array}$ & $\begin{array}{c}-0.4764 \\
\text { (Weak Negative) }\end{array}$ \\
\hline Ficus benghalensis & $\begin{array}{l}0.7236 \text { (Moderate } \\
\text { Positive) }\end{array}$ & $\begin{array}{c}0.797 \\
\text { (Strong Positive) }\end{array}$ & $\begin{array}{c}-0.5318 \text { (Moderate } \\
\text { Negative) }\end{array}$ & $\begin{array}{c}0.4496 \\
\text { (Weak Positive) }\end{array}$ & $\begin{array}{c}-0.8654 \text { (Strong } \\
\text { Negative) }\end{array}$ \\
\hline Ficus glomerata & $\begin{array}{l}0.6769 \text { (Moderate } \\
\text { Positive) }\end{array}$ & $\begin{array}{c}0.7437 \text { (Moderate } \\
\text { Positive) }\end{array}$ & $\begin{array}{c}-0.8342 \text { (Strong } \\
\text { Negative) }\end{array}$ & $\begin{array}{c}-0.7219 \text { (Moderate } \\
\text { Negative) }\end{array}$ & $\begin{array}{c}-0.5155 \text { (Moderate } \\
\text { Negative) }\end{array}$ \\
\hline
\end{tabular}

Table 3: Pearson's correlations coefficient among total phenolics content and in vitro antidiabetic and antioxidant activity of leaves of Ficus species. Data expressed as pearson's correlations coefficient ( $R$ ) between TP Content, mean $(n=3)$ and in vitro antidiabetic and antioxidant activity of respective plant extracts. TP: Total phenolic, $a-A I A$ : $\alpha$ - amylase inhibitory activity, a-GIA: a- glucosidase inhibitory activity, DPPH-RSA: 2,2-diphenyl-1-picrylhydrazyl - radical scavenging activity, RP: Reducing power, HP-RSA: Hydrogen peroxide - radical scavenging activity.

\begin{tabular}{cccccc}
\hline Plant & TP/ & TP/ & TP/ & TP/ & TP/ \\
Name & $\mathrm{aA}$ & $\mathrm{aG}$ & $\mathrm{DPPH}$ & $\mathrm{RP}$ & $\mathrm{HP}$ \\
\hline \multirow{2}{*}{ Ficus religiosa } & -0.0856 & -0.2773 (Weak & 0.7425 (Moderate & 0.5228 & 0.4314 \\
Ficus & (Weak Negative) & Negative) & Positive) & (Moderate Positive) & (Weak Positive) \\
benghalensis & 0.3967 & 0.2639 & -0.4766 & -0.1196 & -0.5583 \\
Ficus glomerata & (Weak Positive) & (Weak Positive) & (Weak Negative) & (Weak Negative) & (Moderate Negative) \\
& (Strong Negative) & (Strong Negative) & (Strong Positive) & (Strong Positive) & (Strong Positive) \\
\hline
\end{tabular}




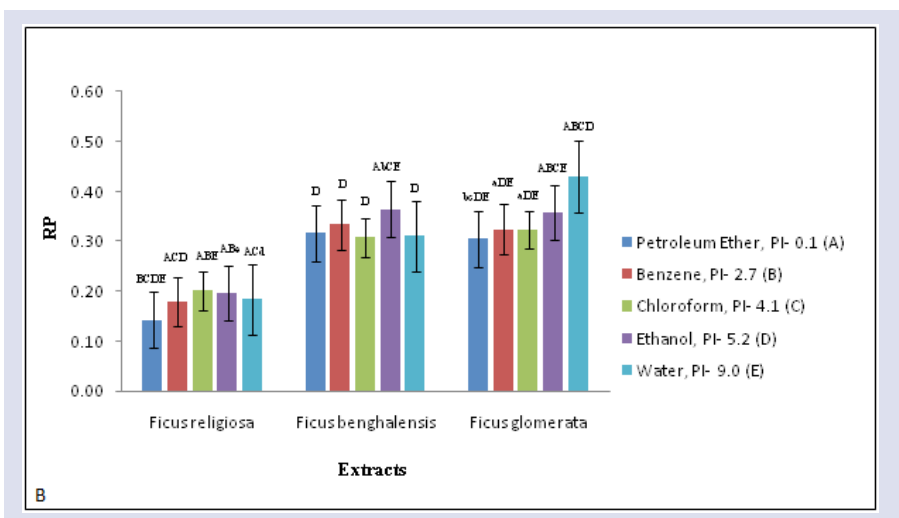

Figure $\mathbf{3}$ (b): In vitro reducing power assay of leaves of Ficus species.

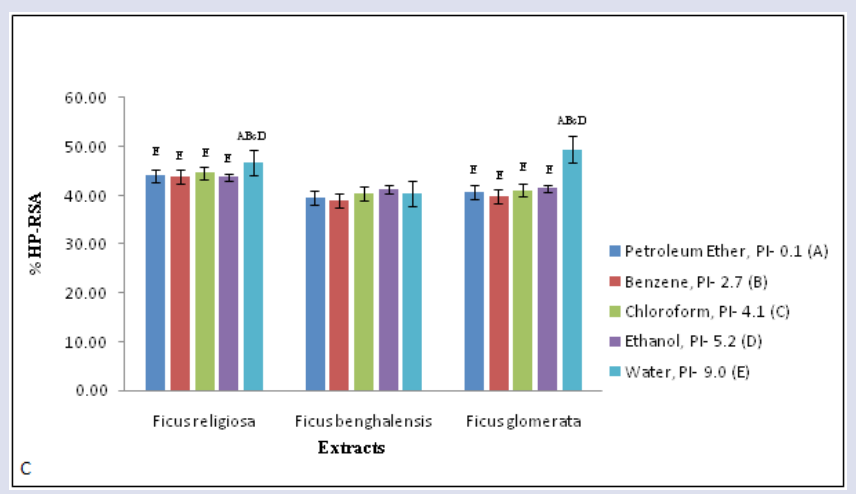

Figure 3 (c): Figure 3 (C): In vitro hydrogen peroxide radical scavenging activity of leaves of Ficus species.

Figure 3: In vitro DPPH radical scavenging activity (A), reducing power (B) and hydrogen peroxide radical scavenging activity (C) of leaves of Ficus species. Data expresses as mean \pm SEM $(n=3)$. Lower case letters indicate significant differences of $P<0.05$ and capital letters indicate significant difference of $P<0.01$ as compared to different solvent extracts. PI: Polarity index, DPPH-RSA: 2, 2-diphenyl-1-picrylhydrazyl - radical scavenging activity, RP: Reducing power, HP-RSA: Hydrogen peroxide - radical scavenging activity

The present findings not only showed comparative in vitro antidiabetic and antioxidant activity of three plants from Ficus species but also give clear idea about the effect of extracting solvents, total flavonoids and phenolic content on in vitro antidiabetic and antioxidant activities of these plants. Among all analyzed leaf extracts, Ficus glomerata leaf extracts showed comparatively high in vitro antidiabetic and antioxidant activity. However, further in vivo studies are needed to confirm the potential of these plants in the treatment of diabetes and oxidative stress related disorders.

\section{CONCLUSION}

Total flavonoids and phenolics content of leaves of three Ficus species were significantly different depending on the types of plant and polarity of solvents used for the extraction. More polar solvent like water seems to be more effective in extracting phenolics content from the leaves. In addition, it should be also noted that statistically significant strong positive correlation was observed between phenolics content and antioxidant activities of Ficus glomerata.

\section{ACKNOWLEDGMENT}

The author wish to thanks Dr. Abdul Razak Honnutagi, Director, AIKTC and Dr. Shariq Syed, Dean, SoP, AIKTC for providing facilities to carry out this work.

\section{CONFLICT OF INTEREST}

We declare that we have no conflict of interest.

\section{ABBREVIATIONS USED}

DPPH: 2,2-diphenyl-1-picrylhydrazyl assay; RP: Reducing power; HP: Hydrogen peroxid; ANOVA: Analysis of Variance; HSD: Honest significant difference; PBS: Phosphate buffer saline; pNPG: Para nitrophenyl - $\beta$-D-glucuronide; $\alpha A$ : $\alpha$-amylase; $\alpha \mathrm{G}$ : $\alpha$-glucosidase; DNS: 3,5-Dinitrosalicylic acid; TFC: Total flavonoids content; TPC: Total phenolics content; QE: Quercetin equivalent; GAE: Gallic acid equivalent, $\boldsymbol{\alpha}$-AIA: $\boldsymbol{\alpha}$ - amylase inhibitory activity; $\boldsymbol{\alpha}$-GIA: $\boldsymbol{\alpha}$ - glucosidase inhibitory activity; DPPH-RSA: 2,2-diphenyl-1-picrylhydrazyl - radical scavenging activity; HP-RSA: Hydrogen peroxide-radical scavenging activity.

\section{REFERENCES}

1. Joshi SR, Parikh RM. India-diabetes capital of the world: now heading towards hypertension. J Assoc Physicians India. 2007;55(Y):323-4.

2. Kumar A, Goel MK, Jain RB, Khanna $P$, Chaudhary V. India towards diabetes control: Key issues. Australas Med J. 2013;6(10):524-31.

3. Kawahito S, Kitahata H, Oshita S. Problems associated with glucose toxicity: Role of hyperglycemia-induced oxidative stress. World J Gastroenterol. 2009; 15(33):4137-42.

4. Ferdinando G, Michael B. Oxidative stress and diabetic complications. Circ Res 2010;107:1058-70.

5. Baby J, Justin SR. Phytopharmacological and phytochemical properties of three ficus species- An overview. Int J Pharm Bio Sci. 2010;1(4):246-53.

6. Ordonez AA, Gomez JD, Vattuone MA, Isla MI. Antioxidant activities of Sechium edule (Jacq.) Swart extracts. Food Chem. 2006;97(3):452-8.

7. Wolfe K, Wu X, Liu RH. Antioxidant activity of apple peels. J Agric Food Chem. 2003;51(3):609-14.

8. Arabshahi S, Urooj A. Antioxidant properties of various solvent extracts of Mulberry (Morusindica L.) leaves. Food Chem. 2007;102(4):1233-40.

9. Oyaizu M. Studies on products of browning reactions: antioxidative activities of products of browning reaction prepared from glucosamine. Jpn J Nutr. 1986;44(6):307-15.

10. Jayaprakasha GK, Jaganmohan RL, Sakariah KK. Antioxidant activities of flavidin proof of concept and $\alpha$-amylase inhibitor in cinnamon. J Agric Food Chem. 2014;62:11465-71.

11. Okutan L, Kongstad KT, Jager AK, Staerk D. High-resolution $\alpha$-amylase assay combined with high-performance liquid chromatography-solid-phase extraction-nuclear magnetic resonance spectroscopy for expedited identification of $\alpha$-amylase inhibitors: proof of concept and $\alpha$-amylase inhibitor in cinnamon. J Agric Food Chem. 2014; 62:11465-71.

12. Kim YM, Jeong YK, Wang MH, Lee WY, Rhee HI. Inhibitory effects of pine bark extract on alphaglucosidase activity and postprandial hyperglycemia. Nutr. 2005;21:756-61.

13. Bahman N, Leyla A, Hamidreza I. $\alpha$-amylase inhibitory activities of six salvia species. Iran J Pharm Res. 2010;7:297-303.

14. Piluzza G, Bullitta S. Correlations between phenolic content and antioxidant properties in twenty-four plant species of traditional ethnoveterinary use in the Mediterranean area. Pharm Biol. 2011;49(3):240-7.

15. Massoumeh F, Ramazan AK, Seyed MB, Foroogh N. Antioxidant activity, total phenolics and flavonoids contents of some edible green seaweeds from northern coasts of the Persian Gulf. Iran J Pharm Res. 2014;13(1):163-70.

16. Xican $L$, Xiaoting $W$, Ling $H$. Correlation between antioxidant activities and phenolic contents of Radix Angelicae Sinensis (Danggui). Mol. 2009;14(12):5349-61.

17. Barchan A, Bakkali M, Arakrak A, Pagan R, Laglao UA. The effects of solvents polarity on the phenolic contents and antioxidant activity of three Mentha species extracts. Int J Curr Microbiol App Sci. 2014;3(11):399-412. 
GRAPHICAL ABSTRACT

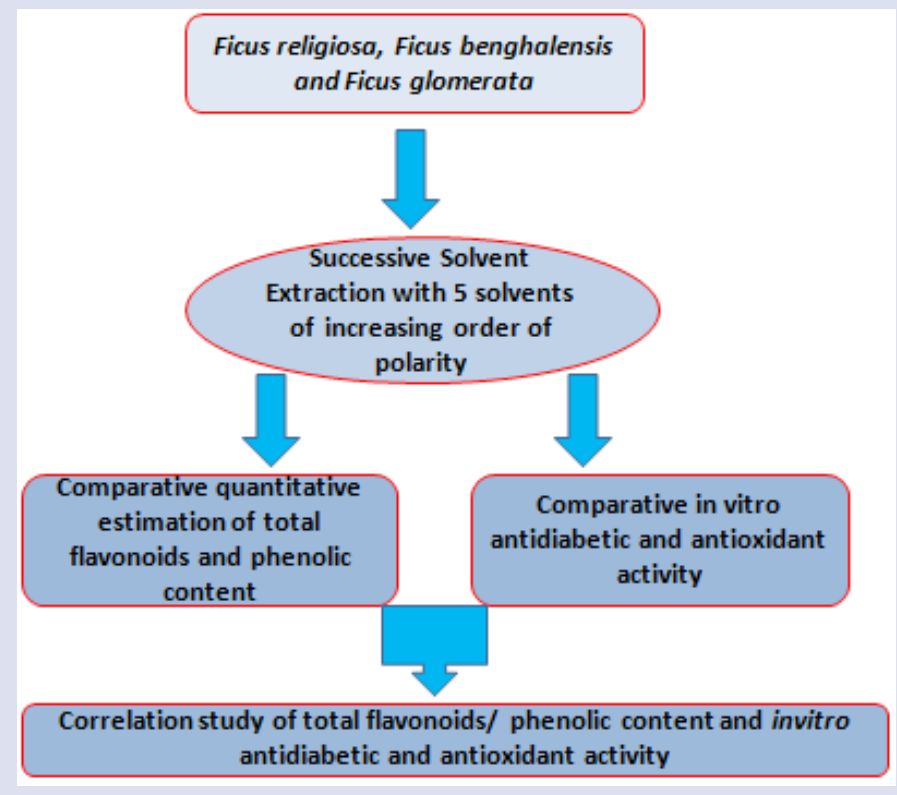

\section{SUMMARY}

- $\quad$ Ficus religiosa (Ashvatha), Ficus benghalensis (Nyagrodha) and Ficus glomerata (Udumbara) are few of the reputed panchavlkal drugs of ayurveda belonging to the family of Moraceae.

- In vitro antioxidant activity of different extracts of these plants has been conducted by DPPH radical scavenging, reducing power and hydrogen peroxide radical scavenging assay. In addition, in vitro antidiabetic activity was also evaluated by using $\alpha$-amylase and $\alpha$-glucosidase inhibitory assay.

- Quantitative phytochemical estimation of total flavonoids and phenolic content has been done to evaluate its correlation with in vitro antioxidant and antidiabetic activity.

- Present study revealed in vitro antioxidant and antidiabetic activity of various extracts from Ficus species. Although these plants are related to the same species but widely differ in their in vitro activities as well as total flavonoids and phenolic content.

Cite this article: Abusufyan S, Ibrahim M, Mohib K. Comparative in vitro Antidiabetic and Antioxidant Activity of Various Extracts of Ficus Species. Pharmacog J. 2018;10(2):349-54. 